\title{
Land use and fragmentation in a dry forest in the Brazilian semiarid
}

The municipality of Campina Grande is the main medium city in the Brazilian semiarid region. Its floristics are formed by the tropical forest (seasonally dry transition) and the Caatinga. In view of this reality, the present study sought to assess the dynamics of land use, map forest fragments from 2010 to 2018 , and study floristics. Remote Sensing and floristic survey techniques were used. There was an increase of $21.6 \%$ in urban and agricultural space, a reduction in fragments of vegetation by $20.2 \%$ and an increase in the regeneration stage by $18.7 \%$. These data show forest fragmentation and loss of biodiversity due to crop rotation mainly in winter On the other hand, there is a succession of pioneer species in this regeneration of the Caatinga. This indicates a decrease in the richness of tree species and, consequently, loss of forest in the municipality during this period.

Keywords: Caatinga; Remote sensing; Tropical forest.

\section{Uso e fragmentação da terra em uma floresta seca no semiárido brasileiro}

O município de Campina Grande é o principal município médio do semiárido brasileiro. Sua florística é formada pela floresta tropical (transição sazonalmente seca) e pela Caatinga. Diante dessa realidade, o presente estudo buscou avaliar a dinâmica do uso do solo, mapear fragmentos florestais de 2010 a 2018 e estudar a florística. Foram utilizadas técnicas de Sensoriamento Remoto e levantamento florístico. Houve um aumento de $21,6 \%$ no espaço urbano e agrícola, uma redução nos fragmentos de vegetação em $20,2 \%$ e um aumento no estágio de regeneração em $18,7 \%$. Esses dados mostram a fragmentação da floresta e a perda de biodiversidade devido à rotação de culturas, principalmente no inverno. Por outro lado, há uma sucessão de espécies pioneiras nessa regeneração da Caatinga. Isso indica uma diminuição na riqueza de espécies arbóreas e, consequentemente, perda de floresta no município neste período.

Palavras-chave: Caatinga; Sensoriamento remoto; Floresta tropical.

Topic: Desenvolvimento, Sustentabilidade e Meio Ambiente

Reviewed anonymously in the process of blind peer.
Received: $11 / 11 / 2020$ Approved: 09/02/2021
Luís Pedro do Nascimento Souza (iD

Universidade Federal de Campina Grande, Brasil

http://lattes.cnpq.br/0817862532002813

http://orcid.org/0000-0002-6314-7179

luispedro15@hotmail.com

\section{Debora Coelho Moura (it)}

Universidade Federal de Campina Grande, Brasil

http://lattes.cnpq.br/4114902987951934

http://orcid.org/0000-0003-2663-2308

debigeo1@hotmail.com

Regiane Farias Batista (iD)

Universidade Federal da Paraíba, Brasil

http://lattes.cnpq.br/8373946111492732

http://orcid.org/0000-0002-3728-4006

regiane.2549@gmail.com

\author{
Cássio Ricardo Gonçalves da Costa (iD \\ Universidade Federal Rural do Semiárido, Brasil \\ http://lattes.cnpq.br/2792104584823593 \\ http://orcid.org/0000-0003-4207-342X \\ cassioagronomoufpb@gmail.com \\ Ailson de Lima Marques (iD \\ Universidade Federal da Paraíba, Brasil \\ http://lattes.cnpq.br/7731519684534647 \\ http://orcid.org/0000-0002-6838-275X \\ marques.ailsonl@gmail.com
}

\section{Referencing this:}

SOUZA, L. P. N.; MOURA, D. C.; BATISTA, R. F.; COSTA, C. R. G.; MARQUES, A. L.. Land use and fragmentation in a dry forest in the Brazilian semiarid. Natural Resources, v.11, n.1, p.92-101, 2021. DOI: http://doi.org/10.6008/CBPC2237-9290.2021.001.0012 


\section{INTRODUCTION}

The municipality of Campina presents a floristic complex formed by the phytoecological region of Deciduous Seasonal Forests that occur in restricted spaces due to the hypothesis raised that this region was a high montane refuge in the Pleistocene when they formed a continuous forest interconnected to the Chaco and the Caatinga, serving as shelter for the different floras in times of drier climate (AB'SABER, 1992). Currently found in the broad stage of fragmentation.

According to Fernandes (1998), this phyto-ecological region, also called on the global scale of "Tropical Dry Forests", refers to tree formations that occur in regions with two seasons (dry and rainy), well defined (MURPHY et al., 1986; OLIVEIRA FILHO et al., 2000; NASCIMENTO et al., 2004; VIEIRA et al., 2006). In the state of Paraíba occur in the areas of Planalto a Borborema, in the Argissolos and Luvissos, in soft, undulating reliefs, in areas between 500-600m altitude (RIBEIRO et al., 1998; PRADO, 2003; SCARIOT et al., 2005).

For Ewel (1999), Deciduous Seasonal Forests are under severe threat of degradation and fragmentation as they provide less stressful environmental and biological conditions for human use and colonization than other regions that tend to be colder, hotter, drier or wetter. In addition, several other political and economic factors have increased the anthropic impacts on dry tropical forests, leading to serious environmental disturbances.

The fragmentation process consequence of environmental degradation affects the organization of natural communities, especially as it reduces the living area of the species by changing local climatic conditions (WHITMORE, 1997). According to Leitão Filho et al. (1995), the isolation of the fragments limits the arrival of dispersers and pollinators from other areas, increasing the risk of local extinction of species represented by few individuals. These changes influence the mosaic cycle, a concept developed by Aubreville (REMMERT, 1991), or plant succession, conceived by studies by Thoreau and Cowles (WHITMORE, 1982; BARNES et al., 1997).

According to Whitmore (1982), forest fragmentation presents several degrees, in terms of the mechanisms or stages of succession, these stages are divided into clearings, be they developmental and mature, which could be arbitrarily distinguished. Generally these fragments are associated with nonproductive areas and are very susceptible to anthropic alterations, as in the case of extractivism and real estate speculation. In this bias, in the anthropic process of habitat fragmentation, the structure of the landscape is modified, resulting in changes in the composition and diversity of the communities.

It is noteworthy that in the Municipality there was an intense urbanization and management of the field in the economic cycles. In the 1940s to 1960s, this growth accelerated continuously, and the outbreak of cotton production served as the driving force behind this expansion. With this continuous acceleration there was a degradation of vegetation and fragments, as well as occupations in inappropriate areas such as Permanent Preservation Areas.

In this sense, detailed studies on the phytoecology, floristic composition and ecology of the vegetal 
communities are fundamental to support any initiatives of preservation and conservation of forest remnants, and through mapping and remote sensing techniques, this research has as objectives: to map and quantify the seasonal forest fragments and analyze their stages of ecological succession in the municipality of Campina Grande.

\section{METHODOLOGY}

\section{Study area}

The municipality of Campina Grande (Figure 1) is located in the mesoregion of the Paraíba agreste, in the microregion of Campina Grande, between coordinates $7^{\circ} 13^{\prime} 39^{\prime \prime S}$ and $35^{\circ} 53^{\prime} 24^{\prime} \mathrm{W}$. The population was estimated in 2010 in approximately 409731 habitants, in a territorial area of $594.18 \mathrm{~km}^{2}$, and a population density of $648.31 \mathrm{hab} / \mathrm{km}^{2}$ (IBGE, 2010).

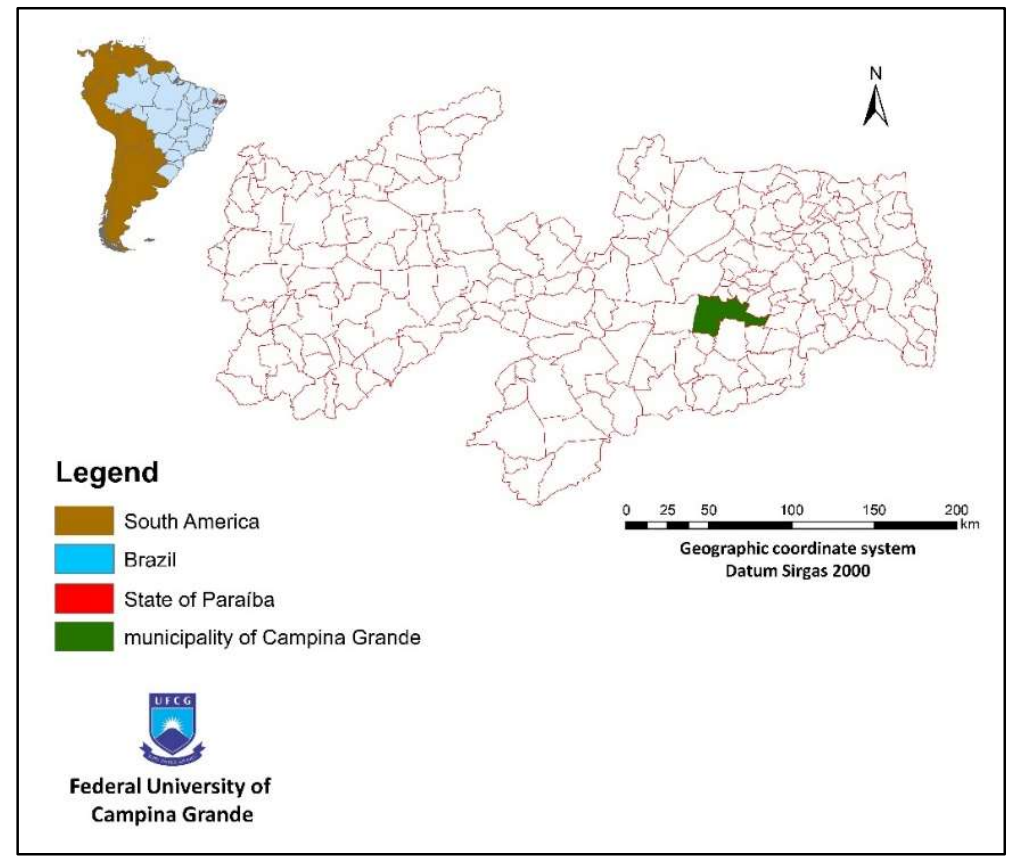

Figure 1: Location map of the study area, municipality of Campina Grande.

The municipality is included in the geographic area covered by the Brazilian semi-arid region, defined by the Ministry of National Integration in 2005. This delimitation has as criteria the rainfall index, the dryness index and the risk of drought.

In addition, the altitude of 552 meters ensures warmer temperatures throughout the year. Temperatures are $30^{\circ}$ on hot days and $18^{\circ}$ on winter days, or $13^{\circ}$ on coldest nights of the year. The relative humidity is between 75 to $82 \%$. The rainy season begins in May and ends in August (CPRM, 2005).

\section{Technical Stages}

\section{Acquisition of satellite images}

The images of the TM sensor Landsat 5 and 8 were acquired on the website of the National Institute of Space Research (INPE). The information corresponding to the orbit, point, day, and angle of elevation of 
the Sun of each image are listed in (Table 1). All bands were used, except for band 6 with spatial resolution of $120 \mathrm{~m}$ and their information is from the thermal band of the electromagnetic spectrum, which for our research does not contemplate our objectives.

Table 1: Images used, point and orbit.

\begin{tabular}{l|l}
\hline Dates & Point and orbit \\
\hline $29 / 08 / 2010$ & $214 / 65$ \\
$24 / 05 / 2018$ & $215 / 65$ \\
\hline
\end{tabular}

\section{Treatment}

In the satellite images used in the research, the Vegetation Indexes were applied as a form of inquiry, aiming at one that would better respond to the mapping of the study areas and all their respective objects. These analyzes were carried out using images from the Landsat 5 and 8 . Two images were selected that were mosaic since the study area contemplates two distinct points in the same orbit. The same occurred for the most recent period (Table 1). The images were used for mapping and quantification of the vegetation cover as a result and the identification of anthropic actions in the Municipality.

\section{Stacking and reprojection}

Erdas Imagine's Raster - set drop point tool was used. From a reference point of an already registered image, being possible orthorectification.

\section{Area Crop}

The clipping of the city of Campina Grande occurred through the creation of shapefille in the ERDAS 2010 and ArcGis 2011 programs, and also using data available from the Brazilian Institute of Geography and Statistics and Geoportal Aesa.

\section{Radiometric Calibration}

It is the computation of the spectral radiance (Equation 1) of each band, that is, the effectiveness of the Radiometric Conversion, in which the digital number (ND) of each pixel of the image is converted into monochromatic spectral radiance. These radiances represent the solar radiation reflected by each pixel, per unit area, time, solid angle and wavelength measured at Landsat (705Km) satellite level for bands 1, 2, 3, 4, 5 and 7; and calibration is performed according to the equation (MARKHAM et al., 1987).

$$
\mathrm{L}_{\lambda \mathrm{i}}=\mathrm{a}_{\mathrm{i}}+\frac{\mathrm{b}_{\mathrm{i}}-\mathrm{a}_{\mathrm{i}}}{255} \mathrm{ND}
$$

Where $\mathrm{a}$ and $\mathrm{b}$ are the minimum and maximum spectral radi; ND is the pixel intensity (digital number - integer 0 to 255); and i corresponds to bands $(1,2, \ldots$ and 7$)$ of the Landsat 5 and bands 1,2,3 y 8 the Landsat 8.

\section{Reflectance Ref:}

Monochrome (Equation 2) of each band, defined as the ratio between the flux of the reflected solar radiation and the flux of incident solar radiation (BASTIAANSSEN et al., 1998; SILVA, 2012). 


$$
\rho_{\lambda \mathrm{i}}=\frac{\pi \cdot \mathrm{L}_{\lambda \mathrm{i}}}{\mathrm{k}_{\lambda \mathrm{i}} \cdot \cos Z \cdot \mathrm{d}_{\mathrm{r}}}
$$

Where $L_{\lambda i}$ is the spectral radiance of each band, $k_{\lambda i}$ is the spectral solar irradiance of each band at the top of the atmosphere $\left(\mathrm{Wm}^{-2} \mu \mathrm{m}^{-1}\right.$, Table 1$), \mathrm{Z}$ is the solar zenith angle and $\mathrm{d}_{\mathrm{r}}$ is the square of the ratio between the average distance Earth-Sun ( $r_{0}$ ) and the distance Earth- day of the year (DAS), which according to lqbal (1983). Where

DAS represents the sequential day of the year and the argument of the 7ós function is in radians. The mean annual value of $d_{r}$ is equal to 1.00 and it ranges from about 0.97 to about 1.03 .

\section{Standard Difference Vegetation Index (IVDN)}

It is obtained (Equation 3 ) by the ratio between the reflectivity of the IV-close $(\rho \mathrm{IV})$ and the red $(\rho \mathrm{V})$, by their sum (ROUSE et al., 1974):

$$
I V D N=\frac{\rho I V-\rho V}{\rho I V+\rho V}
$$

\section{Supervised Classification}

The unsupervised classification was performed using the images corresponding to the dates of 08/29/2010 and 05/24/2018. The entire process was carried out at Erdas 2010 at the Laboratory of Digital Cartography, Geoprocessing and Remote Sensing (CADIGEO) at the Federal University of Campina Grande.

\section{RESULTS AND DISCUSSION}

When analyzing (Figure 2) in relation to the image of the year 2018, we identified the increase in classes related to Agriculture / Exposed Soil, as well as Urban Area, when compared to the year 2010. Analyzing the areas of tropical forest and shrub vegetation was identified fragmentation or decrease in relation to the increase in agrarian and urban space. The bush vegetation is the Caatinga. According to Silva et al. (2013), urban growth in the city of Campina Grande is justified by the strong attractiveness of the city, exercised by its role as a regional pole. The Municipality's geographical position provides an administrative strategy between Cariri, Sertão and the Paraíba coast.

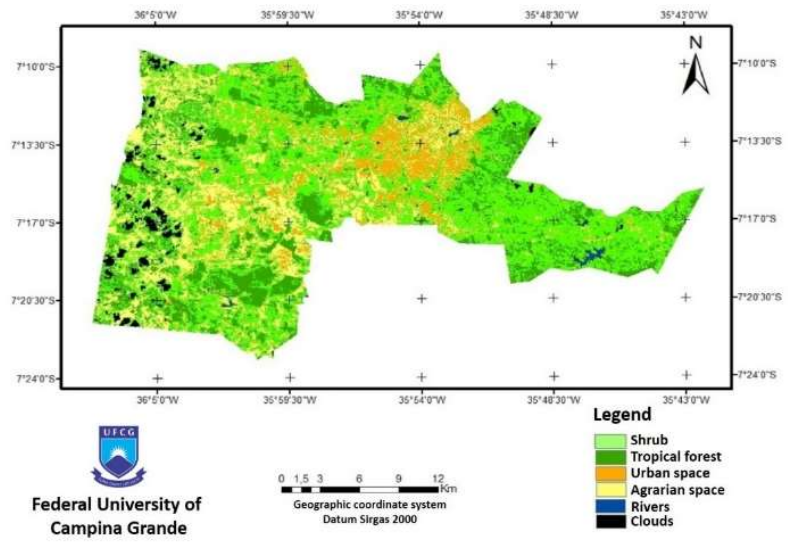

Figure 2: Map of land use and occupation, with image of the year 2018 in the city of Campina Grande - PB.

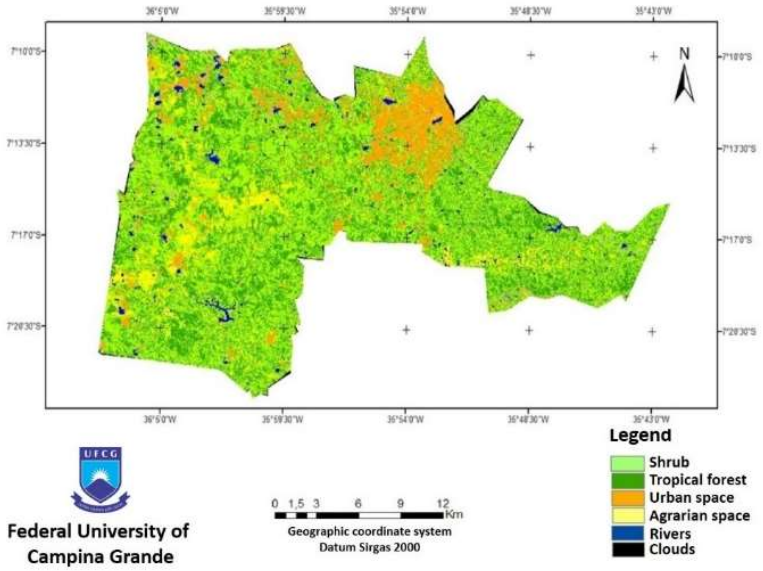

Figure 3: Map of land use and occupation, with image of the year 2010 in the city of Campina Grande - PB. 
When analyzing the image for the year 2010 (Figure 3), we identified areas of Shrub Vegetation well distributed throughout the image. The Urban Area class is concentrated in the center / north portion, while Agriculture / Exposed Soil occurs close to rivers. The tropical and shrub forest generally forms a mosaic of plant formations in different successional stages, however, these stages are influenced by ancient and current land uses.

The vegetation around the city of Campina Grande was studied by Saunders et al. (1991) and Viana and Tabanez (1996) in the 1990s, identified loss of original coverage in the period, caused mainly by urban expansion, only sparse remnants of forest. The fragmentation of vegetation causes the isolation of the remnants, as well as changes in physical and biological characteristics, such as the climate, the soil and consequently the relief, affecting its sustainability.

When quantifying each class for the year 2018 (Table 2) in order to analyze the increase in class suppression over the analyzed periods, it was identified that the class with the greatest expansion was the agrarian space with 101.04 ha over the period. municipality boundary.

Table 2: Quantification of vegetation uses analyzed by Remote Sensing, with image of the year 2018 in the city of Campina Grande - PB.

\begin{tabular}{l|l|l}
\hline Uses & $2018(\%)$ & (ha) \\
\hline Tropical forest & 14,6 & 25.95 \\
\hline Shrub & 11,4 & 19.16 \\
\hline Urban space & 22,0 & 52.29 \\
\hline Agrarian space & 34,8 & 101.04 \\
\hline Rivers & 17,2 & 28.62 \\
\hline
\end{tabular}

It was identified in the 2010 image (Table 3) that the tropical forest presents the most representative with 154.49 ha or $34.2 \%$, followed by Shrub Vegetation with 141.98 ha or $30.1 \%$ of the total area. In this sense, there was a suppression of natural vegetation (Tropical and shrubland) to the detriment of agrarian space in these 18 years.

Table 3: Quantification of vegetation classes analyzed by Remote Sensing, with image of the year 2010 in the city of Campina Grande - PB.

\begin{tabular}{l|l|l}
\hline Uses & Percentage 2010 (\%) & Hectares (ha) \\
\hline Tropical forest & 34,2 & 154,49 \\
\hline Shrub & 30,1 & 141,98 \\
\hline Urban space & 17,5 & 58,46 \\
\hline Agrarian space & 13,2 & 46,44 \\
\hline Rivers & 05,0 & 11,02 \\
\hline
\end{tabular}

In the comparative analysis between the images of 2018 and 2010, the increase in urban space was also registered. Urban and agricultural spaces together in 18 years had an increase of $21.7 \%$, causing the fragmentation of the tropical forest in $20.2 \%$ and the increase in shrub vegetation in different states of regeneration. These varied states of regeneration demonstrate rotational land uses. It is common in the Brazilian semiarid to have a bad culture of making rotational uses of the soil due to the long period of drought and concentration of planting in winter.

With regard to the increase in the Urban Area, Sousa et al. (2013) affirm that the construction of projects, which follows the periurban network of other horizontal condominiums in the City, considerably 
modified the landscape. However, urban expansion promotes the fragmentation of the tropical and shrub forest and, consequently, the reduction and biological loss, causing an imbalance in the ecosystem.

Based on the analysis of the images and the quantification of the vegetation classes analyzed by Remote Sensing, it was diagnosed that there was an increase in fragmentation and also a decrease in its size. Reflecting public interference in the preservation of these areas, as well as the economic pressures experienced in the City when analyzing urban growth.

\section{Phytophysiological Analysis of Ecosystems}

In relation to the results obtained in Campo, areas with tropical forests, shrub species with sparse trees and open shrub were visited. For this methodological stage, it was divided into Six Areas, with intrinsic random sampling.

In the First Area (Lat: 717'35 " S / Long: 3544'51"W), the identification of fragments of tropical forest, where Zizyphus Anadenanthera colubrina (Vell.) Brenan and a vast area of extensive livestock and subsistence agriculture, in addition to Prosopis juliflora (Sw.) It was observed in this degraded area, the presence of shrubs in the regeneration phase, in addition to physiognomies of riparian forest that cover the banks of the rivers that cross the area. In the "Sítio Amorim" location, degraded areas were being occupied by regeneration of Caatinga species, while the windward area, following the stretch of the stream, presented aspects related to a small fragment of Deciduous Seasonal Forest, with undulating relief (Figures 4: A and B). It is worth mentioning that on the BR-230 highway (S7016'52 "/ 3546'10") there is a fragment of tropical forest, but the presence of regenerating vegetation is present. Analyzing the geoenvironmental aspects, Regolitic and Clayey Neossols were found in these areas, originating from gneiss rocks.

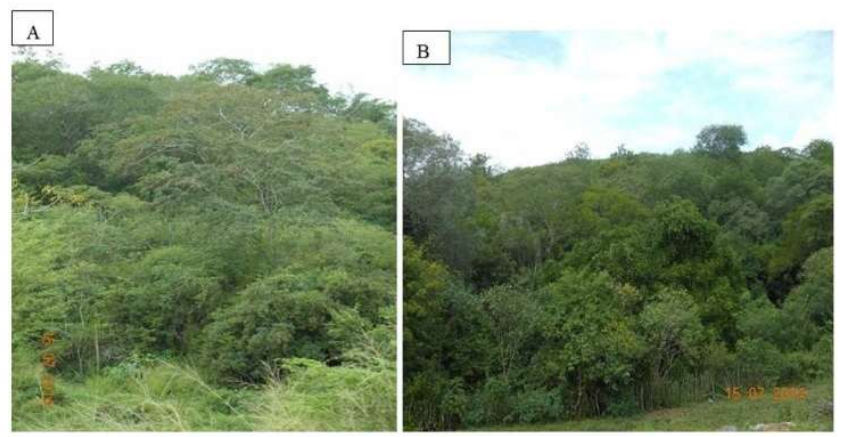

Figures 4: A and B: Deciduous Seasonal Forest fragments in smooth undulating areas of the municipality of Campina Grande - PB.

In the second area (Figures 5: A, B, C and D) fragments of forests were visualized by the 2018 image, when verified in the field the area was covered by fruit trees, subsistence agriculture and livestock. Regarding the vegetation in the area, it was possible to observe regenerating shrubs and sparse trees such as Ziziphus joazeiro Mart; Anadenanthera colubrina (Vell.), Brenan; Enterolobium contortisiliquum (Vell.), Morong. And Pithecellobium dulce (Roxb.) Benth.

The third area (7018'3 " S / 3603'4"W) and D (7020'44"S / 365'23"W), are located the orographic position to the leeward of the municipality of Campina Grande. In view of this orographic position, 
phytophysiognomies have characteristics similar to Caatinga tree shrubs such as: Schinopsis brasiliensis Engl (barauna), Anadenanthera colubrina (Vell.) Brenan (angico), Erythrina velutinaWilld, Tabebuiaaurea (Silva Manso) Benth. \& Hook.f. ex S.Mo., which have a wide geographical distribution, which can be found in the Caatinga and in the Estacional Forest (ANDRADE et al., 2005; RODAL et al., 2005).

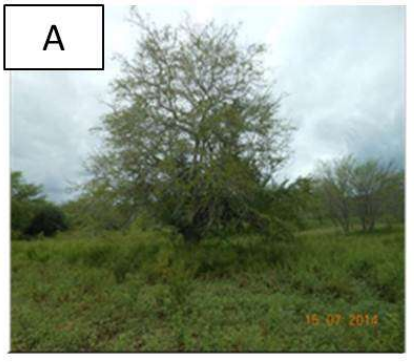

Pithecellobium dulce

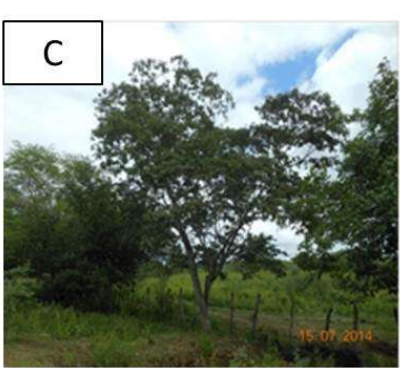

Anadenanthera

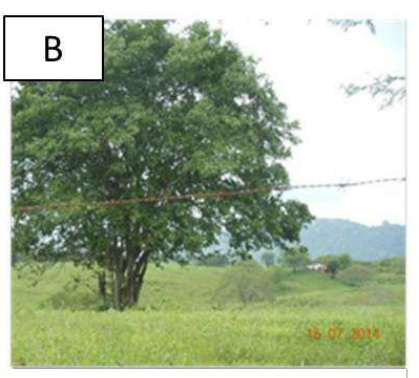

Ziziphus joazeiro Mart.

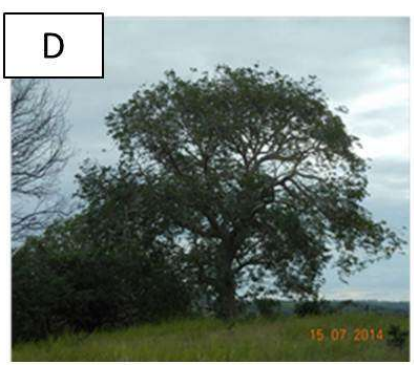

Enterolobium colubrina (Vell.)

Figure 5: Vegetation species of Deciduous Seasonal Forest Fragments, which present a wide geographic distribution in the city of Campina Grande - PB.

In all six areas, 26 families were registered, distributed in 42 species (Table 4). These species were registered in the Decidual and Caatinga Seasonal Forest. Twenty species were recorded, with wide geographical distribution (LIMA et al., 2009), however, 4 species belong to the seasonal forest and 18 species are from the Caatinga biome. The Caatinga species recorded in the study areas are endemic to the biome, according to Albuquerque et al. (2000), Queiroz (2009) and Loiola et al. (2009).

Table 4: Species of Deciduous and Caatinga Seasonal Forest vegetation registered in Campina Grande-PB.

\begin{tabular}{|c|c|c|c|c|}
\hline \multirow[t]{2}{*}{ Family } & \multirow[b]{2}{*}{ Species } & \multirow[b]{2}{*}{ Lifestyle } & \multicolumn{2}{|c|}{ Phytophysiognomies } \\
\hline & & & FED & CAAT \\
\hline Alismataceae & Echinodorus grandiflorus (Cham. \& Schltdl.) Micheli & Water grass & $\mathrm{x}$ & $\mathrm{x}$ \\
\hline \multirow[t]{3}{*}{ Anacardiaceae } & Myracrondruom urundeuva Fr. All. Benth. & Tree & $\mathrm{x}$ & $x$ \\
\hline & Schinopsis brasiliensis Engl. & Tree & $x$ & \\
\hline & Spondias tuberosa Arr. Cam. & Tree & & $x$ \\
\hline Apocynaceae & Aspidosperma pyrifolium Mart. & Tree & & $x$ \\
\hline Asteraceae & Centratherum punctatum Cass. & Herb & $\mathrm{x}$ & $x$ \\
\hline \multirow[b]{2}{*}{ Bignoniaceae } & Handroanthusim petiginosus (Mart. ex DC.) Standl. & Tree & $\mathrm{x}$ & $\mathrm{x}$ \\
\hline & Tabebuia aurea (Benth. \&Hook. f. ex S. Moore & Tree & $x$ & $x$ \\
\hline \multirow[t]{2}{*}{ Boraginaceae } & Cordia multispicataCham. & Herb & $x$ & $x$ \\
\hline & Heliotropium angiospermum Murray & Herb & $x$ & $x$ \\
\hline Bromeliaceae & Bromelia laciniosa Mart. ex Schult. f. & Herb & & $x$ \\
\hline Burseraceae & Commiphora leptophloeos (Mart.) Gillet & Tree & & $x$ \\
\hline \multirow[t]{2}{*}{ Cactaceae } & Tacinga inamoena K. Schum. & Sub-bush & & $x$ \\
\hline & Tacinga palmadora Britton \& Rose & Sub-bush & & $x$ \\
\hline Capparaceae & Capparis flexuosa (L.) & Bush & & $x$ \\
\hline \multirow[t]{2}{*}{ Convolvulaceae } & Ipomoea asarifolia (Desr.) Roem. \&Schult. & Bindweed & $x$ & \\
\hline & Ipomoea nil (L.) Roth & Bindweed & $x$ & $x$ \\
\hline
\end{tabular}




\begin{tabular}{|c|c|c|c|c|}
\hline \multirow{4}{*}{ Euphorbiaceae } & Cnidosculos quercifolius Pohl. & Bush & & $x$ \\
\hline & Cnidoscolus surens (L.) Arthur & Bush & $\mathrm{x}$ & $\mathrm{x}$ \\
\hline & Croton heliotropiifolius Kunth. & Bush & $\mathrm{x}$ & $\mathrm{x}$ \\
\hline & Jatropha molissima (Pohl) Baill. & Bush & & $\mathrm{x}$ \\
\hline \multirow[t]{6}{*}{ Fabaceae } & Dioclea grandiflora Mart. ExBenth & Bindweed & $\mathrm{x}$ & $\mathrm{x}$ \\
\hline & Enterolobium contortisiliquum (Vell.) Morong & Tree & $\mathrm{x}$ & \\
\hline & Erythrina velutina Willd & Tree & & $\mathrm{x}$ \\
\hline & Libidibia ferrea(Mart. Ex Tul. L.P.Queiroz & Tree & $\mathrm{x}$ & $\mathrm{x}$ \\
\hline & Pithecellobium dulce (Roxb.) Benth. & Shrub & $\mathrm{x}$ & $\mathrm{x}$ \\
\hline & Poincianella pyramidalis(Tul.) L.P. Queiroz & Tree & & $\mathrm{x}$ \\
\hline \multirow{4}{*}{ Malvaceae } & Herissantia tiubae (K. Sch.) Briz. & Erva & & $\mathrm{x}$ \\
\hline & Melochia tomentosa $\mathrm{L}$. & Shrub & $\mathrm{x}$ & $\mathrm{x}$ \\
\hline & Sida galheirensi sUlbr. & Shrub & & $\mathrm{x}$ \\
\hline & Waltheria indica $\mathrm{L}$. & Shrub & $x$ & $\mathrm{x}$ \\
\hline Nyctaginaceae & Boerhavia coccinea Mill. & Herb & $x$ & $\mathrm{x}$ \\
\hline Passifloraceae & Turneras ubulata $\mathrm{Sm}$. & Sub-bush & $\mathrm{x}$ & $\mathrm{x}$ \\
\hline Portulacaceae & Portulacae latior Mart. Ex Rohrb & Herb & & $\mathrm{x}$ \\
\hline Plumbaginaceae & Plumbagos candens $L$ & Bindweed & & $\mathrm{x}$ \\
\hline Rhamnaceae & Zizyphus joazeiroMart. & Tree & & $\mathrm{x}$ \\
\hline \multirow[t]{2}{*}{ Rubiaceane } & Richardia grandiflora (Cham. \&Schltdl.) & Herb & $x$ & $\mathrm{x}$ \\
\hline & Staeliavirgata(Cham. \& Schltdl.) K. Schum. & Herb & $x$ & $\mathrm{x}$ \\
\hline \multirow[t]{2}{*}{ Sapindaceae } & Cardiospermum corindum L. & Bindweed & $\mathrm{x}$ & $\mathrm{x}$ \\
\hline & Serjania glabrata Kunth & Bindweed & $\mathrm{x}$ & $\mathrm{x}$ \\
\hline Sapotaceae & Sideroxylon obtusifolium (Humb. ex Roem. \&Schult.) T.D. Penn. & Tree & & $\mathrm{x}$ \\
\hline Verbenaceae & Lantana camara Lindl. & Bush & $\mathrm{x}$ & $\mathrm{x}$ \\
\hline Vitaceae & Cissus verticillata (L.) Nicolson\& C.E. Jarvis & Bindweed & $\mathrm{x}$ & \\
\hline
\end{tabular}

\section{CONCLUSIONS}

As a result of the $21.6 \%$ increase in the Urban and Agricultural areas, there was a $20.2 \%$ reduction in natural vegetation, and an $18.7 \%$ increase in successional strata. The sampling of fragments proves the loss of biodiversity of forest fragments, in contrast to the increase in open areas, urban expansion and agricultural activities. The plant species found in fragments of Deciduous Seasonal Forest are examples of wide distribution, occurring from humid forests, which are located close to the Atlantic coast, to dry forests of the interior (plates located in massifs).

It was noticed that the bush areas increased, but with the regeneration of successive pioneer species in the Caatinga. This indicates a decrease in the richness of tree species with a decrease in the diversity of species of Seasonal Deciduous Forest in the fragments. As there is the effect of fragmentation, the possibility of forest regeneration in succession decreases depending on climatic seasonality in the period of drought or prolonged drought.

\section{REFERENCES}

AB'SABER, A. N.. The Serra do Japi, its geomorphological origin and the refuges theory. In: MORELLATO, L. P.. Ecology and preservation of a forest area in Southeast Brazil. Campinas: UNICAMP, 1992. p.12-23.

ALBUQUERQUE, G. B.; RODRIGUES, R. R.. The vegetation of Morro de Araçoiaba, National Forest of Iperó (SP). Scientia Forestalis, v.58, p.145-159, 2000.

ANDRADE, L. A.; PEREIRA, I. M.; LEITE, U. T.; BARBOSA, M. R. V.. Analysis of the Coverage of Two Phytophysiognomies of Caatinga, with Different Use Histories, in the Municipality of
São João do Cariri, state of Paraíba. However, v.11, n.3, p.253-262, 2005.

BARNES, B.V.; ZAK, D. R.; DENTON, S. R.; SPURR, S. H.. Forest ecology. New York: John Wiley \& Sons, 1997.

BASTIAANSSEN, W. G. M.; PELGRUM, H.; WANG, J.; MORENO, Y. M. J.; ROERINK, G. J.; VAN, D. W. T.. The Surface Energy Balance Algorithm for Land (SEBAL) 2. Validation. Journal of Hydrology, v.212-213, p.213-229, 1998.

CPRM. Geological Survey of Brazil. Diagnosis of the municipality of Campina Grande, state of Paraíba. Project 
designation of sources of groundwater supply. Recife: CPRM, 2005.

EWEL, J. J.. Natural systems as models for the design of sustainable systems of land use. Agroforestry Systems, v.45, n.1, p.1-21, 1999.

FERNANDES, A.. Brazilian Phytogeography. Fortaleza: Multigraf, 1998.

IBGE. Instituto Brasileiro de Geografia e Estatística. IBGE Portal Cities: Campina Grande. IBGE, 2010.

LEITÃO FILHO, H. F.; MORELLATO, L. P. C.. The prospects of the Santa Genebra forest. In: Ecology and Preservation of an Urban Rainforest: Saint Genebrae Reserve. Campinas: University of Campinas, 1995. p.130-134.

LIMA, J. R.; SAMPAIO, E. V. S. B.; RODAL, M. J. N.; ARAÚJO, F. S.. Floristic composition of deciduous seasonal forest Montana de Serra das Almas, CE, Brazil. Minutes Bot. Bra., v.23, n.3, p.756-763, 2009.

LOIOLA, M. I. B.; ROCHA, E. A.; BRACHO, G. S. A.. Flora of Paraíba, Brazil: Combretaceae. Minutes Bot. Bra., v.23, n.2, p.330-342, 2009.

MARKHAM, B. L.; BARKER, J. L.. Thematic Mapper Band Pass Solar Exoatmospherical Irradiances. International Journal of Remote Sensing, v.8, n.3, p.517-523, 1987.

MURPHY, P. G.; LUGO, A. E.. Ecology of tropical dry forest. Annual Review of Ecology and Systematics, v.17, n.1, p.6788, 1986.

NASCIMENTO, R. T. N.; FELFILI, J. M.; MEIRELLES, M. A.. Floristic and structure of the tree community of a remnant of Deciduous Seasonal Forest, Monte Alegre, GO, Brazil. Acta Bot. Bra., v.18, n.3, p.650-669, 2004.

OLIVEIRA FILHO, A. T.; FONTES, M. A.. Patterns of floristic differentiation among Atlantic Forests em Southeastern Brazil and the influence of climate. Biotropica, v.32, p.793810, 2000.

PRADO, D. E.. The caatingas of South America. In: LEAL, I. R.; TABARELLI, M.; SILVA, J. M. C.. Ecology and Conservation of the Caatinga. Pernambuco: University Publishing House UFPE, 2003.

QUEIROZ, L. P.. Leguminosae of the Caatinga. Feira de Santana: Feira de Santana State University, 2009.
RIBEIRO, J. F.; WALTER, B. M. T.. Phytophysiognomies of the Cerrado biome. In: SANO, S. M.; ALMEIDA, S. P.. Cerrado: Environment and Flora. Planaltina: Embrapa-CPAC, 1998. p.89-166.

REMMERT, H.. The mosaic-cycle concept of ecosystems - an overview. In: REMMERT, H.. The mosaic-cycle concept of ecosystems. Berlin: Springer-Verlag, 1991. p.1-21.

RODAL, M. J. N.; LUCENA, M. F. A.; ANDRADE, K. V. S. A. Mata do Toró: a semi-deciduous lowland forest in northeastern Brazil. Hoehnea, v.32, n.2, p.283-294, 2005.

SAUNDERS, D. A.; HOBBS, R.; MARQUES, C. R.. Biological consequences of ecosystem fragmentation: a review. Conservation Biology, v.5, n.1, p.18-35, 1991.

SCARIOT, A.; SEVILHA, A. C.. Biodiversity, structure and conservation of deciduous seasonal forests in the Cerrado. In: SCARIOT, A.; FELFILI, J. M.; SOUZA-SILVA, J. C.. Closed: Ecology, Biodiversity and Conservation. Brasilia: Ministry of the Environment. 2005.

SILVA, J. B.. Remote Sensing Applied to the Study of the Mangrove Ecosystem in Pernambuco. Thesis (PhD in Geography) - Federal University of Pernambuco UFPE. Pernambuco, 2012.

SILVA, M. T.; SILVA, V. P. R.; COSTA, S. C. F. E.. Expansion of the urban space of the city of Campina Grande-PB using remote sensing techniques. In: BRAZILIAN SYMPOSIUM ON REMOTE SENSING - SBSR, 16. Anais. Foz do Iguaçu, INPE, 2013. p.13-18.

SOUSA, A. S.; MELO, J. A. B.; FRANCISCO, P. R. M.. Study of the consequences of real estate expansion on environmental conservation unit: a case of poeta state park. Electronic Controversy, v.12, n.4, p.799-880, 2013.

VIEIRA, D. L. M.; SCARIOT, A.. Principles of natural regeneration of tropical dry forests for restoration. Restoration Ecology, v.14, n.1, p.11-20, 2006.

WHITMORE, T. C.. Tropical forest disturbance, disappearance, and species loss. In: LAURENCE, W. L.; BIERREGAARD, R. O.. Tropical forest remnants: ecology, management, and conservation of fragmented communities. Chicago: The University of Chicago, 1997. p.3-12.

WHITMORE, T. C.. On pattern and process in forests. In: Newman, E. I.. The plant community as a working mechanism. Oxford: Blackwell Scientifi Publications, 1982. p.45-59.

A CBPC - Companhia Brasileira de Produção Científica (CNPJ: 11.221.422/0001-03) detém os direitos materiais desta publicação. Os direitos referem-se à publicação do trabalho em qualquer parte do mundo, incluindo os direitos às renovações, expansões e disseminações da contribuição, bem como outros direitos subsidiários. Todos os trabalhos publicados eletronicamente poderão posteriormente ser publicados em coletâneas impressas sob coordenação da Sustenere Publishing, da Companhia Brasileira de Produção Científica e seus parceiros autorizados. Os (as) autores (as) preservam os direitos autorais, mas não têm permissão para a publicação da contribuição em outro meio, impresso ou digital, em português ou em tradução. 